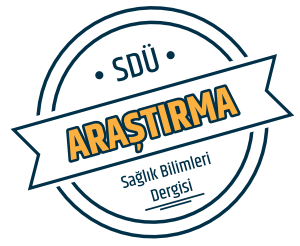

Sdü Sağlık Bilimleri Dergisi / Cilt 10 Sayı 2 / 2019

\title{
Gümüș Nanopartiküllerin Biberiye Özütü ile Biyosentezi ve MCF-7 Meme Kanseri Hücrelerinde Sitotoksik Etkisi
}

\section{Green Synthesis of Silver Nanoparticles using Rosmarinus officinalis and Cytotoxic Effect on MCF-7 Human Breast Cancer Cells}

\author{
Çiğdem Aydın', Suray Pehlivanoğlu² \\ ${ }^{1}$ Mehmet Akif Ersoy Üniversitesi, Bucak Sağlık Yüksekokulu, Burdur, Türkiye. \\ ${ }^{2}$ Necmettin Erbakan Üniversitesi, Fen Fakültesi, Moleküler Biyoloji ve Genetik Anabilim Dalı, Konya, Türkiye.
}

\section{Özet}

Amaç: Gümüş nanopartiküller (AgNP'ler), antimikrobiyal ve dezenfektan maddeler olarak uzun yıllar kullanılmıştır. Bununla birlikte, gümüş nanopartiküllerin antikanser potansiyeli hakkında oldukça sınırlı bilgi mevcuttur. $\mathrm{Bu}$ nedenle, bu çalışmada AgNP' lerin MCF-7 meme kanseri hücreleri üzerindeki sitotoksik etkisinin değerlendirilmesi amaçlanmıştır.

Materyal-Metot: Biberiye (Rosmarinus officinalis) özütü kullanılarak gümüş nanopartiküllerin sentezi için bir biyosentez metodu geliştirildi. Sentezlenmiş gümüş nanopartiküllerin UV-Visible Spektrofotometre ile karakterizasyonu yapıldı. MCF-7 meme kanseri hücreleri çeşitli konsantrasyonlarda AgNP'ler $(0-10 \mu \mathrm{g} / \mathrm{ml})$ ile 24 saat boyunca muamele edildi. Gümüş nanopartiküllerin sitotoksik etkisi MTT test ile belirlendi.

Bulgular: Gümüş iyonlarının bioredüksiyonu 450nm'de spektrofotometrik olarak izlendi. Biberiye özütü kullanılarak hazırlanan AgNP'lerin, 24 saat boyunca MCF-7 meme kanseri hücreleri ile farklı konsantrasyonlarda muamelesi sonrası doza bağımlı olarak hücre büyümesini inhibe ettiği belirlendi.

Sonuç: Bu çalışma ile fiziksel ve kimyasal yöntemlerin yanında bitki özütü kullanılarak gerçekleştirilen AgNP sentezinin iyi bir alternatif olduğu ve biberiye özütü kullanılarak sentezlenen AgNP'lerin meme kanseri tedavisinde potansiyel alternatif bir ajan olabileceği sonucuna varılmıştır. Fakat, gümüş nanopartiküllerin bu etkilerini doğrulamak için in vivo hastalık modellerinin kullanıldığ gereklidir.

Anahtar kelimeler: Gümüş Nanopartiküller, MCF-7, Rosmarinus officinalis, Biberiye.

\section{Giriş}

Kanser dünyada önde gelen ölüm nedenlerinden biridir. Kanser türleri arasında meme kanseri, kansere bağlı mortalite açısından kadınlarda akciğer kanserinden sonra ikinci sırada yer almaktadır. Ayrıca meme kanseri kadınlarda görülen kanserlerin yaklaşık \%30'luk bir dilimini oluşturarak birinci sırada yer almaktadır (1). Cerrahi, radyoterapi ve kemoterapi gibi çeşitli tedavi seçeneklerine rağmen lokal ileri evre ve metastatik meme kanserli hastaların sağ kalım oranlarında

\begin{abstract}
Objective: Silver nanoparticles (AgNPs) have been used as antimicrobial and disinfectant agents for many years. However, there is limited information about the anticancer potential of silver nanoparticles. In this study, we aimed to evaluate the cytotoxic effect of AgNPs on MCF-7 breast cancer cell.
\end{abstract}

Material-Method: A biosynthesis method was developed for the synthesis of silver nanoparticles using rosemary (Rosmarinus officinalis) extract. Synthesized silver nanoparticles were characterized by UV-Visible Spectrophotometer. MCF-7 breast cancer cells were treated with AgNPs $(0-10 \mu \mathrm{g} / \mathrm{ml})$ at various concentrations for 24 hours. The cytotoxic effect of silver nanoparticles was determined by MTT assay.

Results: Bioreduction of silver ions was observed spectrophotometrically at $450 \mathrm{~nm}$. AgNPs prepared using rosemary extract were determined to inhibit cell growth in a dose-dependent manner following treatment with different concentrations of MCF-7 breast cancer cells for 24 hours.

Conclusions: In this study, it is concluded that AgNP synthesis using plant extract is a good alternative besides physical and chemical methods and AgNPs synthesized using rosemary extract can be a potential alternative agent in breast cancer treatment. But, further studies using in vivo disease models are necessary to confirm these effects of silver nanoparticles.

Keywords: Silver Nanoparticles, MCF-7, Rosmarinus officinalis, Rosemary.
DOI: $10.22312 /$ sdusbed. 543053

Müracaat tarihi / Recieved date: 21.03 .2019

Kabul tarihi / Accepted date: 13.05 .2019 ciddi bir artıș olmamıștır. Standart tedavi yöntemleri ile lokal ileri evre meme kanserinde 5 yıllık sağ kalım düzeyi $\% 55$ ve 10 yıllık sağ kalım düzeyi ise $\% 35$ düzeyindedir. Meme kanserli hastalarda tanı ve primer tümörün cerrahi müdahale ile çıkarılması sonrası 10 yıllık süreçte tekrarlama oranı (nüks) \%40 olarak belirlenmiştir (2-6). Tüm bu nedenlerden dolayı meme kanserli hastaların tedavisinde yeni tedavi modellerine ihtiyaç duyulmaktadır.

Nanoteknoloji, bilim ve teknolojideki gelişmeler ile birlikte 
nano ölçekte yeni malzemeler üretmek için ortaya çıkmış ve hızla büyüyen bir alandır (7). Bu teknoloji ile nano ölçek düzeyinde; insan yararına uygun olarak değiştirilmiş, yüzey alanı/hacim oranına bağlı olarak farklı elektriksel, manyetik, optik, fiziksel ve kimyasal özelliklere sahip materyallerin oluşturulması sağlanmaktadır (8). Nanopartiküller çeşitli kimyasal, elektrokimyasal, radyasyon, fotokimyasal ve son yıllarda geliştirilmiş biyolojik metotlar kullanılarak hazırlanabilmektedir. Bununla birlikte, kimyasal sentezlerde kullanılan malzemelerin toksisitesi nedeniyle, nanopartiküllerin sentezinde çevre dostu ve toksik olmayan stabilize edici ajanların kullanılması zorunludur. $\mathrm{Bu}$ bağlamda biyolojik metotlar, fiziksel ve kimyasal metotlar ile karşılaştırıldığında toksik olmayan nanopartiküllerin üretiminde önemli bir avantaj sağlamaktadır. Son yıllarda, nanopartikül sentezinde bitkiözlerinin kullanımı yöntem olarak basit, non-toksik, ucuz ve çeşitli alanlarda uygulanabilirliği nedeniyle oldukça popülarite kazanmıştır (9). Bitki özleri hem nanopartiküllerin sentezinde indirgeyici ajanlar hem de stabilize edici maddeler olarak etki gösterebilirler. Aynı zamanda, bitki özütünün kaynağınında nanopartiküllerin özelliklerini etkilediği bilinmektedir (10). Şu ana kadar çok sayıda çeşitli bitki özütü kullanılarak AgNP'lerin yeşil sentezi gerçekleştirilmiştir (11).

Kanser tedavisinde nanoteknolojiye dayalı kullanılan terapiler minimal yan etkiler ve yüksek özgünlükleri ile son yıllarda oldukça ilgi çekmektedir. Özellikle tıbbi bitkilerden sentezlenerek üretilen nanopartiküller antimikrobiyal, antioksidan ve antikanser etkileri nedeniyle dikkat çekmektedirler (12-14). Son zamanlarda yapılan çalışmalarda, yeşil gümüş nanopartiküllerin farklı kanser türlerinde hücre canlılığını azaltma ve apoptoz arttırma yetenekleri bildirilmiştir (15-17). Bu nedenle araştırmalar daha çok kanser hücrelerine karşı yüksek aktiviteye sahip ancak normal hücrelerde düşük toksisite gösteren yeni gümüş nanopartiküllerin sentezi için antikanser etkili doğal bileşiklerin seçilmesine odaklanmıştır.

Biberiye (Rosmarinus officinalis) Akdeniz bölgesinden köken alarak tüm kıtalara yayılmış hem aromatik hemde süs bitkisi olarak yetiştirilen çok yıllık odunsu bir bitki türüdür. Yaprakları yaygın olarak baharat olarak kullanılır ve tıbbi amaçlara da hizmet eder. Farmakolojik aktivitelerinden sorumlu ana bileşenleri 1,8-sineol $(\% 52,2)$, kafur $(\% 15,2)$ ve $\alpha$-pinendir $(\% 12,4)(18,19)$. Aynı zamanda yapılan çalışmalarda biberiye özütünün antiproliferatif, antioksidan ve antibakteriyel etkilerinin olduğuda gösterilmiştir (20-22).

Bu çalışma ile ilk kez antioksidan özelliğe sahip olan Biberiye (Rosmarinus officinalis) özütü kullanılarak yeşil biyosentez ile gümüş nanopartiküllerin sentezi gerçekleştirilmiştir. Sentezlenen gümüş nanopartiküllerin MCF-7 meme kanser hücre hattı üzerine sitotoksik etkileri gösterilmiştir.

\section{Materyal-Metot}

\section{Gümüş̧ Nanopartiküllerin Hazırlanması ve Karakterizasyonu}

Çalışmada kullanılan Biberiye (Rosmarinus officinalis) bitki örnekleri kurutulmuş olarak satın alındı. Kurutulmuş biberiye yaprakları havanda dövülerek toz haline getirildi. Toz biberiye 0,5gr tartılarak 50ml deiyonize suya karıştırıldı. Karışım mikrodalga firında 1 dakika $(1200$ W, 50Hz) tutuldu ve whatmann no.1 filtre kağıdından süzülerek özüt elde edildi. Gümüş nitrat $\left(\mathrm{AgN0}_{3}\right)$ Sigma Aldrich Chemical'dan (St. Louis, MO, ABD) ticari olarak satın alındı. Sulu bir gümüş nitrat $\left(\mathrm{AgNO}_{3}\right)$ çözeltisi $(5 \mathrm{mM})$ hazırlandı ve oda sıcaklığında gümüş nanopartiküllerin sentezi için kullanıldı. Gümüş nanopartiküllerin sentezi için $100 \mathrm{ml} 5 \mathrm{mM}$ gümüş nitrat $\left(\mathrm{AgNO}_{3}\right)$ solüsyonu ve $10 \mathrm{ml}$ biberiye özütü karıştırılarak mikrodalga firında $(1200 \mathrm{~W}, 50 \mathrm{~Hz}) 1$ dakika tutuldu. Birkaç dakika içerisinde sarıdan koyu kahverengiye olan renk değişimi AgNP'lerin oluşumunu gösterdi.

Gümüş nanopartiküllerin oluşumu UV-visible spektrofotometre ile karakterize edildi. UV-Visible spektrofotometre (T60, PG Instruments) ile 300-600nm dalga boyu aralığında absorbans kaydedildi.

\section{Hücre Kültürü}

İnsan meme kanseri hücre hattı MCF-7, ATCC (American Type Culture Collection)'den ticari olarak satın alındi. Hücrelerin tamamı L-glutamin, esansiyel olmayan amino asitler, sodyum prüvat, \%10 Fetal Bovin serum (FBS) ile desteklenmiş, $100 \mathrm{U} / \mathrm{ml}$ Penisilin ve $100 \mu \mathrm{g} / \mathrm{ml}$ Streptomisin ilave edilmiş DMEM (Dulbecco's modified eagle medium) besiyeri içinde monolayer kültürler olarak $\% 5 \quad \mathrm{CO}_{2}$ lik atmosfer ve $37^{\circ} \mathrm{C}^{\prime}$ lik inkübatörde çoğaltıldı.

\section{MTT Testi}

Hücre canlılığ1, 3-(4,5-dimetiltiyazol-2-il)-2,5-difeniltetrazolyum bromür (MTT) testi ile değerlendirildi. Kısaca, hücreler sayıldı ve ardından 96 kuyucuklu kültür (her kuyucukta $2 \times 10^{5}$ hücre) kaplarına aktarıldı. MCF-7 hücreleri, farklı konsantrasyonlarda sentezlenen AgNP'ler ile $(0-10 \mathrm{ug} / \mathrm{ml}) 24$ saat süre ile inkübe edildi. MTT, $5 \mathrm{mg} /$ ml konsantrasyonda hazırlandı ve her bir kuyucuğa 10ul MTT ilave edildi ve 4 saat süreyle inkübe edildi. Oluşan mor renkli formazon kristalleri daha sonra 100ul dimetil sülfoksit (DMSO) içinde çözüldü. Optik dansite (OD), 570nm dalga boyunda çok kuyucuklu spektrofotometre (Thermo Multiscan GO) plaka okuyucusunda okundu. Sonuçlar, üç bağımsız deneyin ortalaması olarak verildi. Hücre canlılığında \%50 azalma gösteren AgNP konsantrasyonu ( $\mathrm{IC}_{50}$ değeri) GraphPad Prism 8 yazılımı kullanılarak belirlendi. AgNP ile muamele edilmemiş hücreler kontrol olarak kullanıldı. AgNP'lerin hücreler üzerindeki etkisi, aşağıdaki formüle göre hesaplandı, kontrol ile karşılaştırılarak yüzde hücre canlılığı belirlendi:

Hücre Canlılığı Yüzdesi (\%)=ortalama OD/kontrol ODx100.

\section{Bulgular}

\section{Gümüş Nanopartiküllerin Sentezi}

Bu çalışmada, gümüş nanopartiküllerin sentezi için biberiye özütü kullanılmıştır. Gümüş nitrat solüsyonu renksiz, biberiye özütü ise sarı renklidir. Gümüş Nitrat $(5 \mathrm{mM})$ solüsyonuna biberiye özütü eklendi. Reaksiyonu takiben 
sarıdan kahverengiye renk değişiminin görülmesi AgNP'lerin oluşumunu gösterdi (Şekil 1).

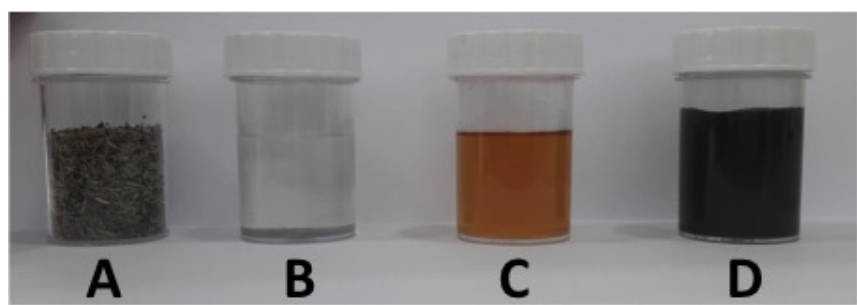

Şekil 1. Biberiye özütü kullanılarak gümüş nanopartiküllerin biyosentezi; (A) Kurutulmuş biberiye bitkisi; (B) Sentez öncesi gümüş nitrat; (C) Biberiye özütü; (D) Sentez sonrası gümüş nanopartikül renk değişimi.

\section{Gümüş Nanopartiküllerin UV VIS Spektrofotometre ile Karakterizasyonu}

UV visible spektrofotometre kullanılarak, hazırlanan AgNP'lerin 300-600nm aralığında absorbsiyonları değerlendirildi. Biberiye özütü kullanılarak hazırlanan AgNP'ler için 450nm'de güçlü ve geniş bir yüzey plazmon piki gözlendi (Şekil 2).

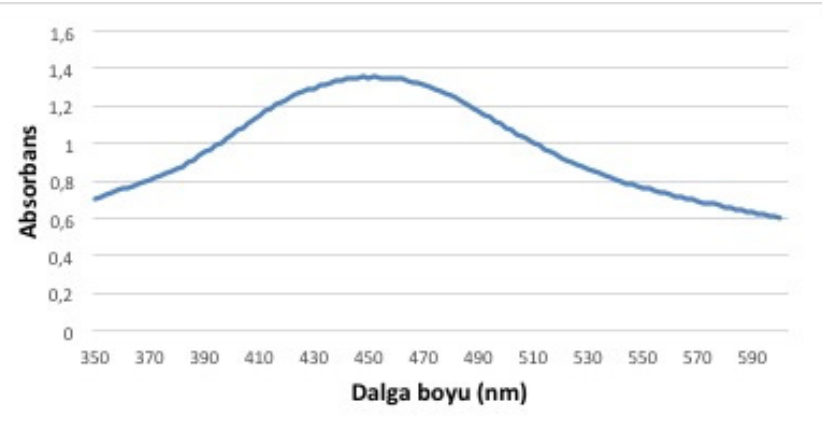

Sekil 2. Gümüş nanopartiküllerin UV-vis absorbans ile karakterizasyonu. Sentezlenmiş gümüş nanopartiküllerin UVgörünür absorbans spektrumu 450nm'de güçlü ve geniş bir pik sergilemiștir.

\section{MCF7 Hücrelerinde AgNP'lerin Doza Bağımlı Sitotoksik Etkisi}

Yapmış olduğumuz çalışmada, gümüş nanopartiküllerin farklı konsantrasyonlarda $(0-10 \mu \mathrm{g} / \mathrm{ml})$ insan meme kanseri hücre hatt1 MCF-7 hücreleri üzerinde in vitro sitotoksisitesi MTT testi ile değerlendirildi. MCF-7 meme kanseri hücreleri farklı konsantrasyonlarda hazırlanmış AgNP'ler ile 24 saat boyunca muamele edildi. Elde ettiğimiz sonuçlar AgNP'lerin MCF-7 hücrelerinde doza bağımlı olarak hücre canlılığını azalttığını gösterdi. AgNP $\mathrm{IC}_{50}$ değeri; $3,32 \mu \mathrm{g} / \mathrm{mL}$ ve $\% 95$ confidence

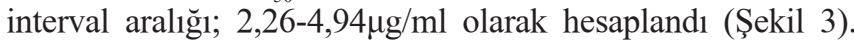
İnkübasyonun 24. saatinde AgNP'lerin $5 \mu \mathrm{g} / \mathrm{ml}$ ve daha yüksek konsantrasyonlarının \%100 sitotoksik olduğu belirlendi. Aynı zamanda, hücre ölümüne yol açan AgNP konsantrasyonlarının bitki özütü ile karşılaştırıldığında çok daha düşük konsantrasyonlarda sitotoksik olduğunu da belirledik (Şekil 4).

\section{Tartışma}

Son yıllarda bilim adamları, bazı sentetik antioksidanların toksik etkileri nedeniyle doğal antioksidanları keşfetmek üzere medikal özelliğe sahip bitkileri araştırmaya odaklanmıştır.

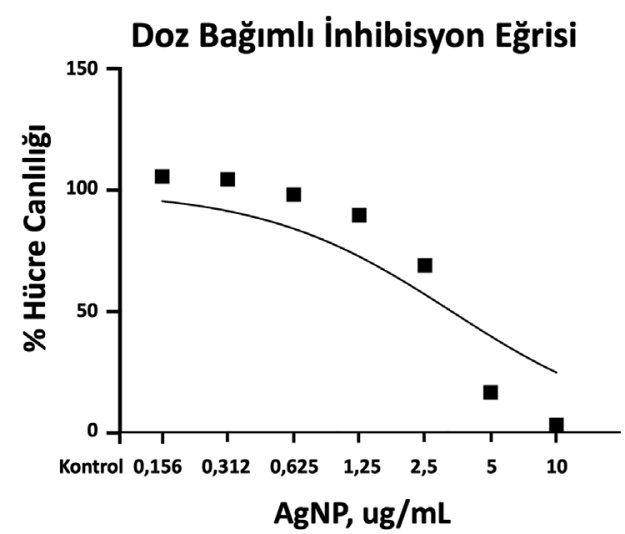

Şekil 3. Gümüş nanopartiküllerin MCF-7 meme kanseri hücreleri üzerindeki doz bağımlı inhibisyon eğrisi. GraphPad Prism 8 yazılımı kullanılarak AgNP'lerin konsatrasyonlarının logaritmik değerleri hesaplanarak inhibisyon eğrisi elde edildi ve buna göre $\mathrm{IC}_{50}$ değeri $(3,32 \mu \mathrm{g} / \mathrm{mL})$ hesapland.

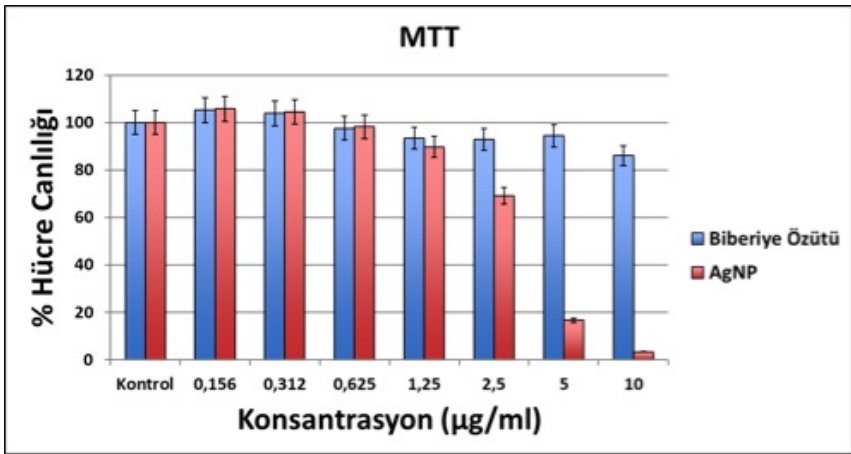

Şekil 4. MCF-7 meme kanser hücrelerinin hücre canlılığ üzerine gümüş nanopartiküllerin (AgNP) doza bağımlı etkisi. Hücreler, 24 saat boyunca çeşitli AgNP konsantrasyonlarında muamele edildi ve sitotoksisite MTT metodu ile belirlendi. Sonuçlar, üç bağımsız deneyin ortalama \pm standart sapması olarak ifade edildi. Kontrol hücrelere göre muamele edilen hücrelerin canlılık oranlarının istatistiksel anlamlılı̆̆1, Student t-testi kullanılarak belirlendi $(* \mathrm{p}<0,05)$.

Ayrıca, doğal antioksidanlar insan sağlığını korumada oldukça önemli bir role sahiptir. Bugüne kadar bitki özleri kullanılarak gümüş nanopartiküllerin biyosentezi ile ilgili çok sayıda çalışma rapor edilmiştir, fakat onların antikanser özellikleri yeteri kadar açıklanamamıştır. Gümüş nanopartiküllerin sentezi için bugüne kadar kullanılmış olan fiziksel ve kimyasal birkaç yöntem mevcuttur (23). Biyolojik yöntemlerin geliștirilmesi, gümüș nanopartiküllerin sentezi ve uygulanması için uygun maliyetli, çevre dostu ve kolay olması nedeniyle oldukça önemlidir. Bu çalışmada, Biberiye özütü kullanılarak hazırlanmış gümüş nanopartiküllerin antikanser potansiyeli ilk kez rapor edilmiştir.

Bitki özütleri, metal iyonlarıyla etkileşime girerek metalik nanopartiküllere indirgeme potansiyeline sahiptir (24). Biberiye özütünde bulunan biyomoleküller, $\mathrm{Ag}^{+}$iyonlarının tek bir adımda $\mathrm{Ag}^{0} \mathrm{a}$ indirgenmesinden sorumludur. Yapmış olduğumuz çalışmada, reaksiyonu takiben sarıdan kahverengiye renk değișiminin görülmesi AgNP'lerin oluşumunu göstermektedir. Sarıdan kahverengiye olan renk değişiminin AgNP'lerin sentezini destekleyen bir delil olduğu 
daha önce yapılan çalışmalarda da gösterilmiştir (25-28).

AgNP'lerin UV-visible spektrofotometre ile karakterizasyonu yapılmıştır. $\mathrm{Bu}$ teknik nanopartiküllerin karakterizasyonu için oldukça önemli bir tekniktir (25-27). 450nm yakınında gözlenen bant, parçacıkların topaklanma olmadan iyi bir dağılım sağladığını göstermektedir. Güçlü fakat geniş yüzeyli plazmon pikinin, 2-100nm genişliğinde çeşitli metal nanopartiküllerin olması durumunda gözlemlendiği iyi bilinmektedir $(25,26)$. Daha önce yapılan çalışmalar ile elde ettiğimiz sonuç uyumlu olarak belirlenmiştir (28).

Yapmış olduğumuz çalışmada, MCF-7 meme kanseri hücreleri farklı konsantrasyonlarda hazırlanmış AgNP'ler ile 24 saat boyunca muamele edilmiş ve ardından hücre canlılıkları MTT testi ile değerlendirilmiştir. Elde ettiğimiz sonuçlar AgNP'lerin MCF-7 meme kanseri hücrelerinde doza bağımlı olarak hücre canlılığını azalttığını göstermiştir. Hücre canlılık testi, toksik maddelere karşı hücresel cevabı açıklayan toksikoloji analizi için önemli yöntemlerden biridir ve hücre ölümü, hayatta kalma ve metabolik aktiviteler hakkında bilgi sağlayabilir (29). Piao ve ark. (30) AgNP'ler ve $\mathrm{AgNO}_{3}$ ün insan Chang karaciğer hücrelerinde doza bağımlı sitotoksisite gösterdiğini ve AgNP'lerin AgNO3 ile karşılaştırıldığında daha yüksek bir sitotoksisite gösterdiğini rapor etmiştir. AgNP ile muamele edilmiş hücrelerin, hücre tipine ve nanopartiküllerin boyutuna bağlı olarak metabolik aktiviteyi azalttığ1 da gösterilmiştir (31). Gurunathan ve ark. (32) bir meme kanseri hücre hatt1 olan MDA-MB-231 hücrelerinde yapmış oldukları çalışmada bir mikroorganizma olan Bacillus funiculus kullanarak yeşil sentez yolu gümüş nanopartiküller sentezlemişlerdir. Çalışmanın sonucunda gümüş nanopartiküllerin 24.saatte laktat dehidrogenaz (LDH), kaspaz-3 ve reaktif oksijen türevlerinin (ROS) aktivasyonu ile doza-bağımlı olarak sitotoksisite gösterdiğini rapor etmişlerdir. Behboodi ve ark. (33) yapmış olduğu çalışmada da, medikal bir bitki olan Cichorium intybus ekstraktı kullanarak hazırladıkları gümüş nanopartiküllerinin MCF7 meme kanser hücrelerinde sitotoksik etki gösterdiği rapor edilmiştir. Jang ve ark. (34) MCF-7 meme kanseri hücrelerinde Lonicera hypoglauca yeşil sentez ile oluşturulmuş ve gümüş nanopartiküllerin sitotoksik etkilerini göstermişlerdir. Meme kanserinin yanısıra literatürde farklı kanser türlerinde gümüş nanopartiküllerin kullanımına ilişkin çalışmalar mevcuttur. Rani ve ark. (35) yeşil sentezlenmiş gümüş nanopartiküllerin insan glioblastoma hücrelerinde, Nagajyothi ve ark. (36) A549 akciğer kanser hücreleri ve MCF-7 meme kanseri hücrelerinde antiproliferatif etkilerini rapor etmişlerdir.

\section{Sonuç}

Son zamanlarda gümüş nanopartiküller tıbbi cihaz kaplamalarında ve özellikle yara bakımında antimikrobiyal ajanlar olarak kullanılmaktadır. Nanoteknolojiyi kullanarak biyouyumlu yeni antikanser ajanların geliștirilmesi ise kanser tedavisi alanındaki yeni yaklaşımlardan biridir. Bu anlamda gümüş nanopartiküllerin kanser tedavisinde kullanımı gündeme gelmiştir. Gümüş nanopartiküllerin sentezinde bitki özlerinin kullanımı diğer bir deyişle nanopartiküllerin biyosentezi oldukça hızlı, temiz, toksik olmayan ve çevre dostu bir teknoloji geliștirilmesinde etkili bir yöntemdir

Yapmış olduğumuz çalışmada, gümüş nanopartiküllerin sentezi için biberiye özütü kullanarak AgNP'leri başarıyla sentezledik ve hazırladık. Ayrıca, yeșil sentez ile oluşturulmuş nanopartiküllerin, MCF-7 meme kanseri hücrelerinde kontrol grubuna göre sitotoksik etki gösterdiğini belirledik. Bu sonuç; biberiye özütüyle hazırlanan AgNP'lerin, meme kanseri tedavisinde antikanser ajanlar olarak kullanılabileceğine işaret etmektedir. Ancak, elde etmiş olduğumuz sonuçların tam anlamiyla uygulanabilmesi, insan vücudunda nasil bir etki göstereceğinin belirlenebilmesi ve etki mekanizmalarının aydınlatılabilmesi için in vivo çalışmaların yapılması gerekmektedir.

\section{Kaynaklar}

1. Siegel RL, Miller KD, Jemal A. Cancer statistics, 2018. CA Cancer J Clin 2018; 68(1): 7-30.

2. Petit T, Wilt M, Velten M, Millon R, Rodier J, Borel C, Mors R, Haegele P, Eber M, Ghnassia JP. Comparative value of tumour grade, hormonal receptors, Ki-67, HER-2 and topoisomerase II alpha status as predictive markers in breast cancer patients treated with neoadjuvant anthracycline-based chemotherapy. Eur J Cancer 2004; 40(2): 205-11.

3. Chua B, Olivotto IA, Weir L, Kwan W, Truong P, Ragaz J. Increased Use of Adjuvant Regional Radiotherapy for NodePositive Breast Cancer in British Columbia. Breast J 2004; 10(1): 38-44.

4. Tominaga T, Takashima S, Danno M. Randomized clinical trial comparing level II and level III axillary node dissection in addition to mastectomy for breast cancer. Br J Surg 2004; 91(1): 38-43.

5. Chopra R. The Indian scene. J Clin Oncol 2001; $19(18$ Suppl): 106S-111S.

6. Welm B, Behbod F, Goodell MA, Rosen JM. Isolation and characterization of functional mammary gland stem cells. Cell Prolif 2003; 36(Suppl 1): 17-32.

7. Albrecht MA, Evan CW, Raston CR. Green chemistry and the health implications of nanoparticles. Green Chem 2006; 8: 417-32.

8. Osuwa JC, Anusionwu PC. Some advances and prospects in nanotechnology: a review. Asian J Inf Technol 2011; 10: 96-100.

9. Akhtar M, Panwar J, Yun YS. Biogenic synthesis of metallic nanoparticles by plant extracts. ACS Sustain Chem Eng 2013; 1: 591-602.

10. Kumar V, Yadav SK. Plant mediated synthesis of silver and gold nanoparticles and their applications. J Chem Technol Biotechnol 2009; 84(2): 151-7.

11. Ghaffari-Moghaddam M, Hadi-Dabanlou R, Khajeh M, Rakhshanipour M, Shameli K. Green synthesis of silver nanoparticles using plant extracts. Korean J Chem Eng 2014; 31: 548-57.

12. Conde J, Doria G, Baptista P. Noble metal nanoparticles applications in cancer. J Drug Deliv 2012; 2012: 751075. 
13. Sur I, Altunbek M, Kahraman M, Culha M. The influence of the surface chemistry of silver nanoparticles on cell death. Nanotechnology 2012; 23: 375102.

14. Singh P, Kim YJ, Wang C, Mathiyalagan R, El-Agamy Farh M, Yang DC. Biogenic silver and gold nanoparticles synthesized using red ginseng root extract, and their applications. Artif Cells Nanomed Biotechnol 2016; 44(3): 811-6.

15. Sankar R, Karthik A, Prabu A, Karthik S, Shivashangari KS, Ravikumar V. Origanum vulgare mediated biosynthesis of silver nanoparticles for its antibacterial and anticancer activity. Colloids Surf B: Biointerfaces 2013; 108: 80-4.

16. Kathiravan V, Ravi S, Ashokkumar S. Synthesis of silver nanoparticles from Melia dubia leaf extract and their in vitro anticancer activity. Spectrochim Acta A Mol Biomol Spectrosc 2014; 130: 116-21.

17. Vasanth K, Ilango K, MohanKumar R, Agrawal A, Dubey GP. Anticancer activity of Moringa oleifera mediated silver nanoparticles on human cervical carcinoma cells by apoptosis induction. Colloids Surf B: Biointerfaces 2014; 117: 354-9.

18. Rašković A, Milanović I, Pavlović N, Ćebović T, Vukmirović S, Mikov M. Antioxidant activity of rosemary (Rosmarinus officinalis L.) essential oil and its hepatoprotective potential. BMC Compl Altern Med 2014; 14: 225.

19. da Silva BN, Nakassugi LP, Faggion POJ, Kohiyama CY, Mossini SA, Grespan R, Nerilo SB, Mallmann CA, Alves Abreu Filho B, Machinski M Jr. Antifungal activity and inhibition of fumonisin production by Rosmarinus officinalis L. essential oil in Fusarium verticillioides (Sacc.) Nirenberg. Food Chem 2015; 166: 330-6.

20. Jardak M, Elloumi-Mseddi J, Aifa S, Mnif S. Chemical composition, anti-biofilm activity and potential cytotoxic effect on cancer cells of Rosmarinus officinalis L. essential oil from Tunisia. Lipids Health Dis 2017; 16(1): 190.

21. de Oliveira JR, de Jesus D, Figueira LW, de Oliveira FE, Pacheco Soares C, Camargo SE, Jorge AO, de Oliveira LD. Biological activities of Rosmarinus officinalis L. (rosemary) extract as analyzed in microorganisms and cells. Exp Biol Med (Maywood) 2017; 242(6): 625-34.

22. Hussain AI, Anwar F, Chatha SA, Jabbar A, Mahboob S, Nigam PS. Rosmarinus officinalis essential oil: antiproliferative, antioxidant and antibacterial activities. Braz J Microbiol 2010; 41(4): 1070-8.

23. Edelstein AD, Cammarata RC. Nanomaterials Synthesis, Properties and Applications. Taylor \& Francis, Boca Raton, Fla, USA, 1996.

24. Kuppusamy P, Yusoff MM, Maniam GP, Govindan N. Biosynthesis of metallic nanoparticles using plant derivatives and their new avenues in pharmacological applications - An updated report. Saudi Pharm J 2016; 24(4): 473-84.
25. Sastry M, Mayya KS, Bandyopadhyay K. pH Dependent changes in the optical properties of carboxylic acid derivatized silver colloidal particles. Colloids and Surfaces A. 1997; 127(1-3): 221-8.

26. Sastry M, Patil V, Sainkar SR. Electrostatically controlled diffusion of carboxylic acid derivatized silver colloidal particles in thermally evaporated fatty amine films. J Phys Chem B 1998; 102(8): 1404-10.

27. Shahverdi AR, Minaeian S, Shahverdi HR, Jamalifar H, Nohi AA. Rapid synthesis of silver nanoparticles using culture supernatants of Enterobacteria: a novel biological approach. Process Biochem 2007; 42(5): 919-23.

28. Kalimuthu K, Babu RS, Venkataraman D, Bilal M, Gurunathan S. Biosynthesis of silver nanocrystals by Bacillus licheniformis. Colloids and Surfaces B. 2008; 65(1): 150-3.

29. Rani PVA, Mun GLK, Hande MP, Valiyaveettil S. Cytotoxicity and genotoxicity of silver nanoparticles in human cells. ACS Nano 2009; 3(2): 279-90.

30. Piao MJ, Kang KA, Lee IK, Kim HS, Kim S, Choi JY, Choi J, Hyun JW. Silver nanoparticles induce oxidative cell damage in human liver cells through inhibition of reduced glutathione and induction of mitochondria-involved apoptosis. Toxicol Lett 2011; 201(1): 92-100.

31. Park MV, Neigh AM, Vermeulen JP, de la Fonteyne LJ, Verharen HW, Briedé JJ, van Loveren H, de Jong WH. The effect of particle size on the cytotoxicity, inflammation, developmental toxicity and genotoxicity of silver nanoparticles. Biomaterials 2011; 32(36): 9810-7.

32. Gurunathan S, Han JW, Eppakayala V, Jeyaraj M, Kim JH. Cytotoxicity of biologically synthesized silver nanoparticles in MDA-MB-231 human breast cancer cells. Biomed Res Int 2013; 2013: 535796.

33. Behboodi S, Baghbani-Arani F, Abdalan S, Sadat Shandiz SA. Green Engineered Biomolecule-Capped Silver Nanoparticles Fabricated from Cichorium intybus Extract: In Vitro Assessment on Apoptosis Properties Toward Human Breast Cancer (MCF-7) Cells. Biol Trace Elem Res 2019; 187(2): 392-402.

34. Jang SJ, Yang IJ, Tettey CO, Kim KM, Shin HM. In-vitro anticancer activity of green synthesized silver nanoparticles on MCF-7 human breast cancer cells. Mater Sci Eng C Mater Biol Appl 2016; 68(1): 430-5.

35. AshaRani PV, Low Kah Mun G, Hande MP, Valiyaveettil S. Cytotoxicity and genotoxicity of silver nanoparticles in human cells. ACS Nano 2009; 3(2): 279-90.

36. Nagajyothi PC, Sreekanth TV, Lee JI, Lee KD. Mycosynthesis: antibacterial, antioxidant and antiproliferative activities of silver nanoparticles synthesized from Inonotus obliquus (Chaga mushroom) extract. J Photochem Photobiol B 2014; 130(5): 299-304 